\title{
EXPLORING EXPERIENCES OF PHYSICAL ACTIVITY IN SPECIAL SCHOOL STUDENTS WITH CEREBRAL PALSY: A QUALITATIVE PERSPECTIVE Chunxiao Li ${ }^{*}$, Shihui Chen ${ }^{* *}$
}

\author{
*National Institute of Education, Nanyang Techlogical University, Singapore \\ **: Department of Health and Physical Education, Hong Kong Institute of Education, Hong Kong
}

Little is known about the physical activity (PA) experiences of school-aged students with cerebral palsy (CP) in both school and community settings. The purpose of this qualitative study was to investigate the PA experiences from special school students with CP. Data were collected through face to face semi-structured interviews with 8 special school students with CP. Interviews were audio taped and converted to verbatim transcriptions and then analyzed using content analysis. The analysis led to four different themes related with participation of PA, which were: (a) sedentary behaviours; (b) enjoyment; (c) motivations; and (d) barriers. It was concluded that participants have not enough PA participation with both positive and negative experiences of PA. Environmental factors and negative attitudes hinder their participations in PA. Lack of sufficient personal supports from professionals, parents, and friends are also big challenges for promoting PA in this population.

KEYWORDS:: physical disability, school-aged students, special education needs

\section{INTRODUCTION}

Cerebral palsy (CP), one of the most commonly occurring medical conditions of childhood that results in a lifelong impairment (Beckung \& Hagberg, 2002), which includes motor disorders and often combine with other sensory and cognitive disabilities (Bax, Goldstein, Rosenbaum, \& Paneth, 2005). Nowadays, health care has been shifting from disability prevention to health promotion (Oakeshott \& Hunt, 2003). Keeping physically active is important for promoting health and it has been documented that regular participation of physical activity (PA) has positive effects on preventing secondary complications (Durstine, 2000) and increasing physical fitness level in children with CP (Odman \& Oberg, 2005). Taub and Greer's (2000) study found that PA can also strengthen social connections, physical skills, and self-worth in this population.

Low levels of PA in people with $\mathrm{CP}$, on the other hand, might decrease their fitness level which results in restricting functional ability and increase the risk of secondary conditions (Damiano, 2006). Regrettably, comparing with people without disabilities, people with $\mathrm{CP}$ reported to be more physically inactive and showed low levels of physical fitness (Buffart, Roebroeck, Rol, Stam, \& van den Berg-Emons, 2008; Maher, Williams, Olds, \& Lane, 2007; Zwier, Jvan schie, Becher, Smits, Gorter, \& Dallmeijer, 2010). Previous studies demonstrated that adults were maintaining the patterns of PA which they acquired during childhood (Trost, 2005). Therefore, it is very necessary to help people with CP develop regular patterns of $\mathrm{PA}$ in their young ages (Eck, Dallmeijer, Beckerman, van den Hoven, Voorman, \& Becher, 2008). Understanding the characteristics of participation in PA for people with $\mathrm{CP}$ is the backbone for intervention of regular PA and thus promoting health.

Previous quantitative studies have been conducted to investigate the characteristics of participation in PA focusing on examining the determinants associated with PA levels. It was found that for school-aged children with $\mathrm{CP}$ of younger age, higher motivation, better gross motor function, and higher IQ may predict greater preferences in PA (Imms, Reilly, Carlin, \& Dodd, 2009; Majnemer, Shevell, Law, Birnbaum, Chilingaryan, 
Rosnbaum et al., 2008; Majnemer, ShikakoThomas, Chokron, Law, Shevell, Chilingaryan et al., 2010; Nieuwenhuijsen, Donkervoort, Nieuwstraten, Stam, Roebroeck, \& Transition Research Group South West Netherlands, 2009), whereas parental stress may hinder their participations of PA (Majnemer et al., 2008).

Qualitative studies investigating experiences of PA in people with $\mathrm{CP}$ have been conducted. Sandstrom et al. (2009) explored how personal and environmental factors affected PA experiences in adults with CP. It was demonstrated that although participants enjoyed PA, they stated needs for professional support to facilitate lifelong PA. Buffart et al. (2009) conducted a focus group interview to study the main barriers and facilitators of PA in young adults with CP. It was indicated that the lack of energy, possible injury, limited PA facilities, and lack of information and knowledge were barriers to engage in PA; instead, fun and social contacts were considered as facilitators (Buffart et al., 2009).

The aforementioned literature demonstrated that little is known about the PA experiences especially for school-aged students with $\mathrm{CP}$ through qualitative research methods (Zwier et al., 2010). Imms (2008) stated that future research in this domain should consider the specifically local factors (e.g., school type and size). Furthermore, most of the previous studies to date were implemented in western countries so that there is a need to examine the PA experiences in the Asian societies (e.g., Hong Kong) as to the cultural differences.

Hong Kong is a Special Administrative Region in China. In the late 1997, the government of Hong Kong started to take actions in terms of including students with disabilities into general school settings. To date, most of students with disabilities are educated in 62 special schools with seven of them are for students with physical disabilities (Education Bureau, 2007). Legislations or related policies have been mandated (e.g., Disability Discrimination Ordinance [1996], The First Hong Kong
Rehabilitation Programme Plan [1976]) to secure the rights for PA participation for persons with disabilities.

To sum up, this qualitative study aimed to gain a deeper insight into the PA experiences (both in and out of school settings) through interviewing special school students with CP in Hong Kong.

\section{Method}

This is a qualitative study design. Data were collected using semi-structured interviews.

\section{Theoretical framework}

PA is defined as "any body movement that requires more energy than resting" (U.S. Department of Health and Human Service, 2008). It includes sports, physical education, physical exercise, or other leisure or recreation activities (e.g., family recreations). The Physical Activity for People with a Disability (PAD) model (van der Ploeg, van der Beek, van der Woude, \& van Mechelon, 2004) was used for guiding the present study. According to the PAD model (c.f., Ploeg et al., 2004), PA behaviours or levels of PA in persons with $\mathrm{CP}$ will be influenced by several personal and environment factors. The environment factors consist of social influence (e.g., family, friends, health professionals), facilitators/barriers (e.g., transportation, availability and accessibility facilities or equipment). The personal factors include health condition (e.g., diseases and injury), facilitators/barriers (e.g., motivation, energy, time, and money).

\section{Participants}

Twelve students enrolled in a special school in Hong Kong were purposefully selected with maximum variation strategies for this study (Patton, 1990). Participants had to meet the following inclusion criteria: (i) the special school student; (ii) the student with $\mathrm{CP}$; and (iii) the Chinese who is able to understand and answer the questions during the interview. The special school was recruiting students with physical disabilities especially for those with $\mathrm{CP}$. 
Students from this school were selected mainly because the principal investigator was a part-time Tai Chi educator there. The principal investigator (i.e., interviewee) and students knew each other well and that increased the validity and reliability for the data collection. During the time of administering interviews, there were about 100 students studying in the school. Special physical education was a compulsory subject for the students and was provided by school teachers twice every week for $35 \mathrm{~min}$.

Eight out of twelve students ( 3 males and 5 females) with $\mathrm{CP}$, aged from 11 to 16 years (Mean $=14.4, S D=1.9)$ consented to join the study. Participants with functional level I-V with regards to Gross Motor Function Classification System (GMFCS) were included (Palisano, Rosenbaum, Walter, Russel, Wood, \& Galuppi, 1997). The GMFCS classifies the gross motor function into five levels ranging from level I (almost without motor problems) to level $\mathrm{V}$ (with severe disabilities or motor problems). Table 1 illustrates information of the eight participants. Permission for conducting the study was approved by human research ethic committee from the Institution of the investigators. All informed consents were collected from the participants.

\section{Procedure}

The interviews focused on the students' experiences of participation and perceptions of PA in and outside the school setting. Eight face to face interviews took place in the special school. All interviews were semistructured and were conducted by the first author with rich experience in delivering physical activity services to students with physical disabilities. The interview began with general questions (e.g., what is your name?). Typical questions guiding the interview were mainly as follows: "How often do you participate in physical activity every week in school/out of school?" "What physical activity/sport have you participated?" "What motivates you to/not to participate in physical activity?" "What do you think about participating in physical activity?" "What is your experience in participating in physical activity?" "Do you have barrier(s) to join physical activity?" "How could others help you better participating in physical activity?" Follow-up questions for probing additional examples or information were used (Kvale, 1996). Each interview was tape recorded and lasted between 31 and $46 \min ($ Mean = 36.4).

\section{Data analysis}

Audio tapes were converted to verbatim transcriptions (Chinese). A content analysis method was used for analyzing the full transcripts (Fiese \& Bickman, 1998). The content analysis method is to describe a phenomenon that can be used for identifying patterns or themes without taking "a priori" theories when doing the analysis. The method includes coding participants' statements in terms of their key concepts, combing the coded concepts, and refining the identified themes (Fiese \& Bickman, 1998). Two researchers independently coded transcripts and then compared results. At the very beginning, six themes were found by the first researcher, while only five themes were identified by the second researcher. The disagreement was reevaluated and discussed according to the original transcripts in order to reach the agreement. Six themes were grouped into four themes after the reevaluation and discussion. These preliminary results were presented to four of the participants as a process of validation (Hsieh \& Shannon, 2005). Their feedbacks confirmed the accuracy interpretation of the interview texts. Finally, college students majoring in English were invited to translate the finalized Chinese verbatim transcriptions into English for avoiding authors' misinterpretation or over interpretation of the data.

\section{Results}

The analysis of data from the eight study participants emerged four common themes related with the experiences for participation in PA: (a) sedentary behaviors; (b) enjoyment; (c) motivations; and (d) barriers. The themes 
were illustrated by direct quotes. The number specified subject (see Table 1). in bracket after each quotation represented a

Table 1 Characteristics of the Participants $(n=8)$

\begin{tabular}{|c|c|c|c|c|c|}
\hline $\begin{array}{l}\text { Participants } \\
\text { (Bracket Number) }\end{array}$ & Gender & Age & $\begin{array}{l}\text { GMFCS } \\
\text { Level }\end{array}$ & $\begin{array}{l}\text { Assistive } \\
\text { Device }\end{array}$ & $\begin{array}{l}\text { Out of School PA (event, } \\
\text { frequency, duration) }\end{array}$ \\
\hline 1 & $\mathrm{~F}$ & 16 & $\mathrm{I}$ & No & $\begin{array}{l}\text { Track \& field, 2-3 } \\
\text { times/week, } 25-50 \mathrm{~min}\end{array}$ \\
\hline 2 & $\mathrm{~F}$ & 16 & V & $\begin{array}{l}\text { Powered } \\
\text { Wheelchair }\end{array}$ & $\begin{array}{l}\text { Throwing beanbag, } 1-2 \\
\text { times/week, } 10-15 \mathrm{~min}\end{array}$ \\
\hline 3 & $\mathrm{~F}$ & 15 & II & No & No \\
\hline 4 & M & 16 & IV & $\begin{array}{l}\text { Powered } \\
\text { Wheelchair }\end{array}$ & No \\
\hline 5 & M & 11 & II & No & $\begin{array}{l}\text { Throwing } \\
\text { beanbag/jogging, } 2 \\
\text { times/week, 15-20 min }\end{array}$ \\
\hline 6 & $\mathrm{~F}$ & 12 & III & $\begin{array}{l}\text { Walker/Gait } \\
\text { Trainer }\end{array}$ & No \\
\hline 7 & M & 14 & III & $\begin{array}{l}\text { Walker/Gait } \\
\text { Trainer }\end{array}$ & No \\
\hline 8 & $\mathrm{~F}$ & 15 & II & Gait trainer & $\begin{array}{l}\text { Walking/running, } 1-2 \\
\text { times/week,10-20 min }\end{array}$ \\
\hline
\end{tabular}

Note. GMFCS = Gross Motor Function Classification System; PA = Physical Activity.

\section{Sedentary behaviours}

Study participants demonstrated low levels of participation of PA. Most of them participated in PA less than three times for limited time each week. Table 1 gives further information on out of school PA participations in the study participations. Most often participates indicated activities requiring limited skills (e.g., throwing sandbag, walking and jogging) that were done at home or nearby their home location.

"Throwing beanbags is what I usually do when doing exercise..." (2)

"I never participated any out of school physical activity...now I don't participate either..." (3)

"Sometimes, I participate in physical activity... I

like jogging in the gym... the gym is not far away

from my house..." (5)

"Generally, if I am planning to do exercise, I will go walking or jogging when I am back home after school... Once or twice for each week...sometimes I jog for $10 \min . . . "(8)$

Instead of participation in PA, study participants preferred sedentary activities like reading, watching $\mathrm{TV}$, and surfing the internet.
For some participants shopping was a family activity during weekends in Hong Kong. "Besides doing physical activity, I watch TV and read comic books in my spare time." (1)

"I don't do any exercise after school...I normally do my homework first ...then I watch TV, surf the internet, or play online games." (6)

"Every weekend, my parents and I usually go shopping downtown...yes, as I know some of my classmates will go shopping and eating during weekend, it is a family recreation activity, quite typical in Hong Kong and it is very crowded outside." (5)

\section{Enjoyment and motivation as facilitators}

Most students with CP considered PA bringing them joy and happiness. They enjoyed doing it with family members (e.g., parents, and sisters) or friends as their PA companions.

"Play computer games or doing PA? I would like to choose PA... because many of my friends are there [playground out of school]." (1)

"My personal PA experiences are joyful, not unhappy experiences for me." (4)

"I am happy with doing PA... there are some people in the gym [out of school PA] and they are 
very nice...they teach me how to use the equipments..." (5)

Being healthy (e.g., lose weight and prevention of the deterioration of motor function) was a motivation for being physically active.

"Running or ... maybe other forms of PA can help with losing weight...I want to keep fit and in shape... which will make me look better." (8)

"I just feel so relaxed after exercise...I forget things that made me sad..." (5)

Three participants mentioned that chances to join sports competition drove them engage in PA. However, this kind of motivation was "seasonal" which mean these participants only join PA more often when there were competitions.

"I join the athletic team for training [segregated athletic sessions only for persons with disabilities] in X playground [fictitious name]...three to four times each week..." (1)

"I start practicing throwing beanbags when there are competitions coming... so far, I have got many awards in competitions" (5)

Furthermore, PA was motivated by physical educators and friends. The encouragement from these people was great help for promoting PA for health.

"Chan Sir [fictitious name, the physical educator in the special school] always encourages me to joining as much PA as I can... whenever he finds that I am becoming lazy, he helps me to get motivated again..." (4)

"Lily [fictitious name] is my best friend within this school...yes, we are in the same class...she usually say 'add oil' to me when I attempt to participate in sports competition or in school PE lessons." (8)

\section{Barriers}

Participation in PA did not always bring experiences of happiness or enjoyment. Some participants, on the contrary, mentioned bad PA experiences because doing PA resulted in fatigue, pain, injury, complication, and being bullied. Also, lack of professional training in PE may also hinder the PA participation. These factors made them feel sad and stop "wasting" energy on doing PA.

"I stop to play when I am tired or when I feel pains on my hands [school PE lesson]... The physical education lesson offered by Chan Sir [fictitious name, the physical education teacher in the special school] lasts too long and I was burn out, I don't like the physical education lesson..."." (3)

"...they [other people or peers] laugh at me because I look different...sitting in the wheelchair...this is unfair...I feel uncomfortable [occurred during inclusive PA settings].” (2)

Although joining sports competitions can increase the PA in $\mathrm{CP}$ population as aforementioned, some participants complained that PE teachers, in most cases, only selected those students with better sports skills or performance in order to win.

"It is quite disappointed as our PE teachers only select those classmates with better sports skills...they only consider to win the competitions" (6)

"Yes, I agree that winning is important, but I hope I can join the competition as well...maybe more sports games should be held next year..." (7)

Unexpectedly, the body function of participants was not identified as a big barrier for participation of PA. The most identical factor that affected participation in PA was partnership. The participants complained the lack of PA partners to play with.

"You know what...I don't think my mobility problems stop me from participating in PA." (2)

"Participation in exercise is just very hard...it makes my breathing hard...but if some friends can play with me, I think it makes a lot of differences." (3)

The personal support (e.g., parents, and professionals) was necessary for promoting PA. Parents' values affected the levels of participation of PA in students with CP. Lack of professionals who know how to and can teach sports skills was the other barrier identified.

"My mother say YES or NO [regarding whether I can participate in PA or not]...I don't have a right to take or not to take part in exercises...I feel helpless...I don't know why." (7)

"I never feel any convenience caused by my body; I just need someone who can teach me how to play...so that someone can play with me." (4)

Moreover, sports equipment refrained from participating in exercises or PA. It was a big challenge for students with $\mathrm{CP}$ to purchase expensive equipment as they were not sure whether that equipment was worth investing in or not. Purchasing 
equipments also posed financial burden for some families.

“... few equipment in the $\mathrm{X}$ sports centre [fictitious name] are specific for us [people with special needs]... purchasing expensive equipment for myself is unrealistic...I am not sure if it is really necessary to buy an equipment." (5)

"I don't think it is a realistic way to buy equipments...my family can't afford it....and there is not additional place to put those equipments in my home." (6)

\section{Discussion}

This qualitative study explored the within and out of school PA experiences from the perspectives of special school students with CP in Hong Kong. Most participants demonstrated preferences in sedentary activities (e.g., reading, watching TV, and surfing the internet) with low levels of PA in each week. The same result was described in other studies (Buffart et al., 2008; Maher et al., 2007; Zwier et al., 2010).

The low levels of PA in this population might lead to the risk of secondary complications. Some of our participants said that they usually went shopping with their family members during weekends, which is an active lifestyle and leisure activity in Hong Kong society that should be persisted in future. In addition, even though participants did engage in some PA and those events were with low skill levels such as throwing sandbag, walking, and jogging. This was also consistent with previous study conducted by Majnermer et al. (2008); they found most children with CP involved in lower skillbased physical activities.

Both positive and negative experiences were embedded together in the PA experiences. Law et al.'s (2006) study illustrated similar results. Most students with $\mathrm{CP}$ expressed that they were "having fun" when doing PA with families and their friends. Negative PA experiences, however, were stated by some participants caused by fatigue, pain, injury, and complication related with the disability. Moreover, in the inclusive PA settings, bullying was a typical source of negative experiences, which has been a critical environmental factor that hinders successful social inclusion (Law et al., 2006).
Some studies found that children with disabilities are at risk of being bullied by their peers (Law et al., 2006). This study, again, demonstrated that it is still necessary to create a positive atmosphere for integrating people with CP.

Personal psychological factors that enhance the health promotion PA were, for example, weight management, prevention of motor function deterioration, sports competitions, and encouragements by parents and physical educators. These factors were comparable to the general population (van der Horst et al., 2007). The facilitator like sports competitions is important for exercise maintenance (van der Ploeg et al., 2006); however, it was found to be a "seasonal" factor for students with $\mathrm{CP}$ in this study. Physical educators and parents can play a vital role in promoting PA in people with $\mathrm{CP}$. They can inform participants about importance of PA and encourage them to overcome the barriers related to PA. In contrast to the role of facilitators, some parents did not allow their children with $\mathrm{CP}$ to join exercise. Majnemer et al. (2008) also found that parental stress was an obstacle to participation. This may be because parents of children with $\mathrm{CP}$ held the low sport value or they might be afraid of harassment by other people to their children during the course of PA participation (Tsai \& Fung, 1999).

Interestingly, the gross motor function of students with CP was not identified as a big barrier for participating in health promotion PA. This was inconsistent with previous studies. For example, Imms et al. (2009) investigated the extent to which selected factors related with participation of children with $\mathrm{CP}$ and the results showed that better gross motor function associated with higher participation. This could be due to the different research design since rather than using a cross-sectional survey as in Imms et al's study (2009), the present research used a qualitative method to collect the data.

The barrier to access the transport to get to PA participation in young adults with $\mathrm{CP}$ was identified in the study by Buffart et al. (2009). However, that was not the case for the 
present study. This can be because Hong Kong has a well-developed transportation service system even for wheelchair users. The most identical barriers for participation of participants were lack of professional support and sports partners. Although there is an argument on the necessity to educate adapted physical activity experts (Shikako-Thomas et al., 2008), professional support was able to maximize the participation (Shikako-Thomas et al., 2008). This study proved a need for educating adapted physical activity experts. Participants were eager to find friends, peers or partners to engage in PA with them. Partnership, although was not prominent in the interviews, its critical role in creating social and friendship opportunities for children with restricted mobility was identified (Tamm \& Skar 2000). Lack of sports facilities and equipments had negative effects on participation of PA of children with $\mathrm{CP}$; this was also described in other studies (e.g., Buffart et al., 2009; Zwier et al., 2010).

\section{Limitations and implications}

Although limited studies were conducted to investigate the PA experiences in special school students with CP. This study subjected to a number of limitations. The results of this study were based on a small sample size and convenient sampling, which may hinder the generalization of the results. However, a maximum variation sampling strategy was used (Patton, 1990).

Regardless of the limitations, the present study has several implications for practice. First, this work reinforced the problems of sedentary behaviors in students with $\mathrm{CP}$. The interventions for promoting PA should not only be implemented but should also be early as it is always difficult to integrate PA into daily life in adulthood (Sandstrom et al., 2009). Second, there is a need for creating an inclusive social atmosphere for reducing the environmental barriers (e.g., bullying) for helping CP population better involvement in PA. Third, more sports meetings or competitions should be held in future, especially for those with lower level sports skills, as a way for motivating the participation in PA. In addition, PE teachers should consider the "feelings" of those students with low sports performance when selecting students for competitions. Finally, attentions should be paid to use personal supports from professionals, parents, and physical educators to help students with $\mathrm{CP}$ better participating in PA. Special PE teachers should be well-trained to provide a qualified PE lessons for students with CP (Chen, Lau, \& Jin, 2006; Li, Chen, \& Zhang, 2010).

In conclusion, the present findings indicated that special school children with $\mathrm{CP}$ have low levels of PA. Both positive and negative experiences of PA are found. Environment factors like lack of facilities and negative attitudes hinder the participation in PA. Lack of sufficient personal supports from professionals, parents, and friends are one of major challenges for promoting health PA in this population.

\section{REFERENCES}

Bax, M., Goldstein, M., Rosenbaum, P., \& Paneth, N. (2005). Proposed definition and classification of cerebral palsy. Developmental Medicine \& Child Neurology, 47, 571-576.

Beckung, E., \& Hagberg, G. (2002).

Neuroimpairments, activity limitations, and participation restrictions in children with cerebral palsy. Developmental Medicine \& Child Neurology, 44, 309-316.

Buffart, L. M., Roebroeck, M. E., Rol, M., Stam, H. J., \& van den Berg-Emons, R. J. (2008). Triad of physical activity, aerobic fitness and obesity in adolescents and young adults with myelomeningoccle. Journal of Rehabilitation Medicine, 40, 70-5.

Buffart, L. M., Westendorp, T., van den BergEmons, R. J., Stam, H. J., \& Roebroeck, M. E. (2009). Perceived barriers to and facilitators of physical activity in young adults with childhood-onset physical disabilities. Journal of Rehabilitation Medicine, 41, 881-885.

Chen, S., Lau, K. O., \& Jin. M. (2006). Students' attitudes toward including students with disabilities in regular PE settings in Hong Kong and Taiwan. The Asian Journal 
of Exercise and Sports Science, 3, 35-39.

Damiano, D.L. (2006). Activity, activity, activity: Rethinking our physical therapy approach to cerebral palsy. Physical Therapy, 86, 1534-1540.

Durstine, J. L., Painter, P., Franklin, B. A., Morgan, D., Pitetti, K. H., \& Roberts, S. O. (2000). Physical activity for the chronically ill and disabled. Sports Medicine, 30, 207219.

Eck, M., Dallmeijer, A. J, Beckerman, H., van den Hoven, P. A. M., Voorman, J., \& Becher, J. G. (2008). Physical activity level and related factors in adolescents with cerebral palsy. Pediatric Exercise Science, 20, 95106.

Education Bureau (2007). Inclusion.

Retrieved on July 1, 2008, from http://www.edb.gov.hk/index.aspx?nodeID= 7400\&langno $=2$

Fiese, B. H., \& Bickman, N. L. (1998). Qualitative inquiry: An overview for pediatric psychology. Journal of Pediatric Psychology, 23, 79-86.

Hsieh, H. F., \& Shannon, S. E. (2005). Three approaches to qualitative content analysis. Qualitative Health Research, 15, 1277-1288.

Imms, C. (2008). Children with cerebral palsy participate: A review of the literature.

Disability \& Rehabilitation, 30, 1867-1884.

Imms, C., Reilly, S., Carlin, J., \& Dodd, K. J. (2009). Characteristics influencing participation of Australian children with cerebral palsy. Disability \& Rehabilitation, 31, 2204-2215.

Kvale, S. (1996). Interviews an introduction to qualitative research interviewing.

California: Thousand Oaks.

Law, M., King, G., King, S., Kertoy, M. K., Hurley, P., Rosenbaum, P., Young, N., \& Hanna, S. (2006). Patterns of participation in recreational and leisure activities among children with complex physical disabilities. Developmental Medicine \& Child Neurology, 48, 337-342.

Li, C., Chen, S., \& Zhang, J. (2010). A status analysis of the integrated physical education in Hong Kong elementary schools. Asian Journal of Exercise and Sports Science, 7 , $35-41$.
Maher, C. A., Williams, M. T., Olds, T., \& Lane, A. E. (2007). Physical and sedentary activity in adolescents with cerebral palsy. Developmental Medicine \& Child Neurology, 49, 450-457.

Majnemer, A., Shikako-Thomas, K., Chokron, N., Law, M., Shevell, M., Chilingaryan, G., Poulin, C., \& Rosenbaum, P. (2010). Leisure activity preferences for 6- to 12year-old children with cerebral palsy. Developmental Medicine \& Child Neurology, 52, 167-173.

Majnemer, A., Shevell, M., Law, M., Birnbaum, R., Chilingaryan, G., Rosnbaum, P., \& Poulin, C. (2008). Participation and enjoyment of leisure activities in schoolaged children with cerebral palsy. Developmental Medicine \& Child Neurology, 50, 751-758.

Nieuwenhuijsen, C., Donkervoort, M., Nieuwstraten, W., Stam, H. J., Roebroeck, M. E., \& Transition Research Group South West Netherlands (2009). Experienced problems of young adults with cerebral palsy: targets for rehabilitation care.

Archives of Physical Medicine and Rehabilitation, 90, 1891-1897.

Oakeshott, P., \& Hunt, G. M. (2003). Longterm outcome in open spina bifida. British Journal of General Practice, 53, 632-636.

Odman, P., \& Oberg, B. (2005). Effectiveness of intensive training for children with cerebral palsy - a comparison between child and youth rehabilitation and conductive education. Journal of Rehabilitation Medicine, 37, 263-270.

Palisano, R., Rosenbaum, P., Walter, S., Russel, D., Wood, E., \& Galuppi, P. (1997). Development and reliability of a system to classify gross motor function in children with cerebral palsy. Developmental Medicine \& Child Neurology, 39, 214 -223.

Patton, M. Q. (1990). Qualitative evaluation and research methods (2nd ed). Newbury Park, CA: Sage.

Sandstrom, K., Samuelsson, K., \& Oberg, B. (2009). Prerequisites for carrying out physiotherapy and physical activity experiences from adults with cerebral palsy, Disability \& Rehabilitation, 31, 161-169. 
Shikako-Thomas, K., Majnemer, A., Law, M., \& Lach, L. (2008). Determinants of participation in leisure activities in children and youth with cerebral palsy: systematic review. Physical \& Occupational Therapy in Pediatrics, 28, 155-169.

Tamm, M., \& Skar, L. (2000). How I play: Roles and relations in the play situations of children with restricted mobility. Scandinavian Journal of Occupational Therapy, 7,174-182.

Taub, D.E., \& Greer, K. R. (2000). Physical activity as a normalizing experience for school-age children with physical disabilities. Journal of Sport and Social Issues, 24, 395-414.

Trost, S. G. (2005). Discussion paper for the development of recommendations for children's and youths' participation in health promoting physical activity. Canberra: Australian Department of Health and Ageing.

Tsai, E. H., \& Fung, L. (2009). Parents' experiences and decisions on inclusive sport participation of their children with intellectual disabilities. Adapted Physical Activity Quarterly, 26, 151-171.

U.S. Department of Health and Human Service (2008). 2008 physical activity guidelines for Americans. Retrieved on 5 Jan 2012, from http://www.health.gov/PAGuidelines/pdf/pa guide.pdf

van der Horst, K., Paw, M. J., Twisk, J. W., \& van Mechelen, W. (2007). A brief review of correlates of physical activity of children and adolescents. Medicine \& Science in Sports \& Exercise, 39, 1241-1250.

van der Ploeg, H. P., Streppel, K. R., van der Beek, A. J., van der Woude, L. H., Vollenbrock-Hutten, M. M., \& van Harten, W. H. et al. (2006). Counseling increases physical behaviour nine weeks after rehabilitation. British Journal of Sports Medicine, 40, 223-229.

van der Ploeg, H. P., van der Beek, A. J., van der Woude, L. H., \& van Mechelon, W. (2004). Physical activity for people with a disability: A conceptual model. Sports Medicine, 34, 639-649.

Zwier, J. N., van schie, P. E. M., Becher, J. G., Smits, D., Gorter, J. W., \& Dallmeijer, A. J. (2010). Physical activity in young children with cerebral palsy. Disability \& Rehabilitation, 32, 1501-1508.

Corresponding author's e-mail address: cxlilee@gmail.com

\title{
(Abstract) \\ UNTERSUCHUNG DER BEWEGUNGSERFAHRUNGEN VON SCHÜLERINNEN MIT CEREBRALPARESE IN DER SONDERSCHULE AUS QULITATIVER PERSPEKTIVE Chunxiao Li ${ }^{*}$, Shihui Chen ${ }^{* * *}$
}

\author{
* National Institute of Education, Nanyang Techlogical University, Singapore \\ ** Department of Health and Physical Education, Hong Kong Institute of Education, Hong Kong
}

Man weiß wenig über Bewegungserfahrungen (BE) von Schüler(inne)n mit Cerebralparese (CP) im Setting Schule und Gemeinde. Die Absicht dieser qualitativen Studie war es, die Bewegungserfahrung von Schüler(inne)n mit CP einer Sonderschule zu untersuchen. Die Datenerhebung erfolgte mit persönlichen semistrukturierten Interviews mit acht Sonderschüler(inne)n mit CP. Die Interviews wurden mit Tonband aufgenommen, wörtlich transkribiert und danach mit der Methode der Inhaltsanalyse analysiert. Die Analyse ergab folgende vier verschiedene Themen im Zusammenhang mit der Teilnahme an Bewegungsaktivitäten: (a) sitzende Verhaltensweisen; (b) Vergnügen; (c) Motive; (d) Barrieren. Man konnte daraus schließen, dass die Teilnehmenden nicht genug Teilnahmegelegenheiten an Aktivitäten und damit sowohl positive als auch negative Bewegungserfahrungen haben. Umgebungsfaktoren und negative 
Einstellungen behindern ihre Beteiligung an Bewegung. Der Mangel an ausreichend persönlicher Unterstützung durch Expert(inn)en, Eltern und Freunde bewirkt ebenso große Herausforderungen für die Bewegungsförderung in dieser Zielgruppe.

SCHLÜSSELWÖRTER: körperliche Behinderung, Schüler/innen, sonderpädagogischer Förderbedarf

\begin{abstract}
(Аннотацця)
ИЗУЧЕНИЕ СУБЬЕКТИВНОГО ОТНОШЕНИЯ ШКОЛЬНИКОВ С ЦЕРЕБРАЛЬНЫМ ПАРАЛИЧОМ К ФИЗИЧЕСКОЙ АКТИВНОСТИ: КАЧЕСТВЕННАЯ ТОЧКА ЗРЕНИЯ Чуньсяо Ли, Шихуи Чен **

* Национальный институт образования, Технологический университет Сингапура г.Наньяна ** Департамент здравоохранения и физической культуры, Гонконгский институт образования, Гонконг

Мало что известно о субъективном отношении к испытываемой физической нагрузке школьников с церебральным параличом (ДЦП), учащихся, как в школе, так и по месту жительства. Целью этого качественного исследования было изучение субъективных ощущений детей из специальных школ с ДЦП. Данные были собраны на основе структурированных интервью, проводимых лично с учащимися из 8 специальных школ с ДЦП. Интервью были записаны на пленку и преобразованы в транскрипции дословно, а затем проанализированы с помощью контент-анализа. Анализ привел к четырем различным типам, связанным с переносимостью физической нагрузки: (а) сидячее поведение, (б) просто переносимость, (в) мотивация и (г) барьеры. Был сделан вывод, что испытуемым, как с положительными ощущениями, так и с отрицательными, не хватает физической активности. Факторы окружающей среды и негативное отношение препятствуют их вовлечению в физическую культуру. Существуют большие проблемы, связанные с участием в физической активности этой группы населения и недостатком индивидуальной поддержки со стороны специалистов, родителей и друзей.
\end{abstract}

КЛЮЧЕВЫЕ СЛОВА: инвалидность, икольный возраст, учащиеся, спечиальные образовательные потребности

(Resumen)

EXPLORACIÓN DE LAS EXPERIENCIAS DE ACTIVIDAD FÍSICA EN ESTUDIANTES

DE LA ESCUELA ESPECIAL CON PARÁLISIS CEREBRAL: UNA PERSPECTIVA

CUALITATIVA

Chunxiao Li ${ }^{*}$, Shihui Chen ${ }^{* *}$

* National Institute of Education, Nanyang Techlogical University, Singapore

** Department of Health and Physical Education, Hong Kong Institute of Education, Hong Kong

Poco se sabe acerca de las experiencias en actividades físicas (PA) de los estudiantes en edad escolar con parálisis cerebral (PC) en la escuela y la comunidad. El propósito de este estudio 
cualitativo fue investigar las experiencias en PA de los estudiantes con parálisis cerebral en la escuela especial. Los datos fueron recolectados a través entrevistas cara a cara semi-estructuradas con 8 estudiantes con parálisis cerebral de escuelas especiales. Las entrevistas fueron grabadas en audio y se convirtieron en transcripciones textuales, siendo analizadas posteriormente mediante análisis de contenido. El análisis reveló cuatro diferentes temas relacionados con la participación en PA, que fueron las siguientes: (a) los comportamientos sedentarios; disfrute (b); motivaciones (c), y las barreras (d). Se concluyó que los participantes no realizan PA suficiente y que tuvieron tanto experiencias positivas como negativas en PA. Los factores ambientales y las actitudes negativas obstaculizan sus participaciones en el PA. La falta de suficientes apoyos personales por parte de profesionales, padres y amigos también son grandes desafíos para la promoción de PA en esta población.

PALABRAS CLAVE: discapacidad física, los estudiantes en edad escolar, necesidades educativas especiales

\title{
(Resumo) \\ EXPLORANDO EXPERIÊNCIAS DO ACTIVIDADE EM ESTUDANTES DE ESCOLAS ESPECIAIS COM PARALISIA CEREBRAL: UMA PERSPECTIVA QUALITATIVA
}

\author{
Chunxiao Li ${ }^{*}$, Shihui Chen ${ }^{* *}$ \\ ${ }^{*}$ National Institute of Education, Nanyang Techlogical University, Singapore \\ ** Department of Health and Physical Education, Hong Kong Institute of Education, Hong Kong
}

O conhecimento sobre as experiências de actividade física (AF) de estudantes em idade escolar com paralisia cerebral tanto em contexto escolar como comunitário é muito reduzido. O objectivo deste estudo qualitativo foi investigar as experiências de actividade física de estudantes de escolas especiais com PC. Os dados foram recolhidos através da realização de 8 entrevista semiestruturadas com estudantes de escolas especiais com PC. As entrevistas foram gravadas e transcritas para verbatim e posteriormente analisadas usando a análise de conteúdos análise levou à identificação de quatro temas diferentes relacionados com a participação na AF: (a) comportamento sedentário; (b) diversão; (c) motivações e (d) barreiras. Conclui-se que os participantes não apresentavam um nível suficiente de participação em AF, simultaneamente com experiências positivas e negativas de AF. Os factores do envolvimento e as atitudes negativas são obstáculos à sua participação na AF. A falta de apoio pessoal dos profissionais, pais e amigos são também grandes desafios para a promoção da AF nesta população.

PALAVAS-CHAVE: Deficiência física, estudantes em idade escolar, necessidades educativas especiais 